\title{
Influence of Soil Type, Sowing Date and Diluted Seawater Irrigation on Seed Germination, Vegetation and Chemical Constituents of Moringa oleifera, Lam.
}

\author{
M. A. Hegazi ${ }^{1}$ \\ ${ }^{1}$ Department of Horticulture (Floriculture), Faculty of Agriculture, Kafr El-Sheikh University, Kafr El-Sheikh, \\ Egypt
}

Correspondence: M. A. Hegazi, Department of Horticulture (Floriculture), Faculty of Agriculture, Kafr El-Sheikh University, Kafr El-Sheikh, Egypt. Tel: 20-106-603-3059. E-mail: abohegazi@yahoo.com

Received: November 9, 2014 Accepted: December 15, 2014 Online Published: February 15, 2015

doi:10.5539/jas.v7n3p138 URL: http://dx.doi.org/10.5539/jas.v7n3p138

\begin{abstract}
Two pot trials were conducted during the period of February 15 - October 15 of 2012 and 2013 seasons at two different locations, to evaluate the effect of soil type, sowing date and diluted seawater irrigation on: germination percentage in the first trial and on both plant vegetation and leaves chemical constituents of moringa (Moringa oleifera, Lam.) in the second one. The results showed that, generally, Kafr El-Sheikh area (Agricultural area where clayey soil and Nile River water is available) outperformed Balteem area (coastal area where soil is silty clay and seawater is available) in most studied characters. Lowest seawater ratios in Moringa oleifera irrigation water gave the best results for germination \%, growth characters and some chemical and mineral contents as total green color, leaf protein, total carbohydrates, nitrogen, potassium, calcium and magnessium whereas, the highest ratios gave the best results for phosphorus and sodium contents.
\end{abstract}

Keywords: Moringa (Moringa oleifera), soil type, sowing date, diluted seawater

\section{Introduction}

Moringa (Moringa olifera, Lam.) belongs to family Moringaceae. It is a fast growing, drought tolerant able to tolerate poor soil (Joly, 1979). Moringa tree is drought and salt tolerant and low nutrients requirements (Fuglie, 1999). It produces a tuberous taproot which helps explain its observed tolerance to drought conditions (Ramachanran \& Gopalakrishnan, 1980). It is cultivated for multiple purposes because all its parts including seeds, stems, shoots, leaves, flowers, fruits and roots are useful and many farmers are taking interest to cultivate it as field crop for fodder and vegetable production (Amaglo, 2007; El-Dabh et al., 2011). The tree is particularly renowned for its great versatility, as its uses include being a food source for humans and animals alike, coagulant for water purification, remedy for numerous ailments as well as a source for biofuel production (Anwar et al., 2007; Peixoto et al., 2011; Pontual et al., 2012). Morirga alifera, Lam seeds have an oil content of between $35-40 \%$ which was recently analyzed and found suitable for the production of biofuel in the form of biodiesel (Rashed et al., 2008).

One of the most urgent global problems especially in Egypt after the latest developments in the upstream of the River Nile is the lack of irrigation water. Since Egypt, overlooking both Mediterranean and Red Sea, where they could be used as a renewable source of irrigation water by choosing the salt-tolerant plant species as moringa. Nearly every country in the world experiences water shortages during certain periods of the year (Gleick, 1993), and more than 80 countries now suffer from serious water shortages (Jin et al., 2007). Agricultural production consumes more freshwater than any other human activity. To cope with the scarcity of freshwater for the sustainable development of agriculture, there is increasing awareness among agricultural scientists and planners in the utilization of seawater (at least diluted) for irrigation of crops (Fang \& Chen, 1997; Jin et al., 1999; Liu et al., 2003).

The aim of this research was to study how to expanding in moringa (Morirga alifera, Lam.) tree afforestation at the edges of roads and waterways in all villages and towns of the province of Kafr El-Sheikh, Egypt, and the possibility of using diluted seawater to irrigate these trees especially in the coastal areas, for its benefits not only in human and animal feed, but also the many medical uses, in addition to providing the Nile water to irrigate 
basic crops such as wheat and cotton.

\section{Materials and Methods}

Two pot trials were conducted during 2012 and 2013 seasons at two different locations of Kafr El-Sheikh Governorate to evaluate the effect of soil type, sowing date and diluted seawater irrigation on moringa (Moringa oleifera, Lam.) as follow:

a - Effect on seed germination percentage.

b - Effect on plant vegetation and leaves chemical constituents.

Two different represented areas in both irrigation water source and soil type were carefully selected, the first was Balteem (coastal area) where, seawater and silty clay soil are available. The second one was the city of Kafr El-Sheikh (Agricultural area), where is featuring with freshwater (Demietta branch of Nile River) and clayey soil as the treatments have been conducted under both selected areas.

\subsection{Plant Material and Procedure}

i. First trial: Moringa seeds were collected from a certain mother shrubs grown in some private nurseries during the summer and Autumn months of the above year, sown in plastic tea cups $250 \mathrm{ml}$ filled with the same area soil which the experiment carried out at every sowing date, as one seed in each cup and placed into $75 \%$ network home, where the germination experiment took only four weeks before transplanting in $30 \mathrm{~cm}$ diameter pots. Samples of the two Experimental areas soils were taken and preserved for analysis. The physical and chemical characteristic of experimental soils were provided (Table 1).

Table 1. Physical and chemical analysis of the used soil (Mean of both seasons)

\begin{tabular}{|c|c|c|c|c|c|c|c|c|c|}
\hline Soil area & Sand & Silt (\%) & Clay & Soil texture & $\mathrm{EC}(\mathrm{mmhos} / \mathrm{cm})$ & $\mathrm{pH}$ & Total N (ppm) & Total P (ppm) & $\mathrm{OM}(\%)$ \\
\hline Kafrelsheikh & 8.13 & 41.33 & 48.57 & Clayey & 0.45 & 738 & 55 & 28 & 1.61 \\
\hline \multirow[t]{3}{*}{ Balteem } & 14.17 & 60.01 & 25.63 & Silty clay & 0.90 & 7.85 & 23 & 11 & 045 \\
\hline & \multicolumn{4}{|c|}{ Soluble cations (meq/l) } & \multicolumn{5}{|c|}{ Soluble anions (meq/l) } \\
\hline & $\mathrm{Na}^{+}$ & $\mathrm{K}^{+}$ & $\mathrm{Ca}^{++}$ & $\mathrm{Mg}^{++}$ & $\mathrm{CO}_{3}^{-}$ & $\mathrm{HCO}_{3}^{-}$ & $\mathrm{Cl}^{-}$ & $\mathrm{SO}_{4}{ }^{2-}$ & \\
\hline Kafrelsheikh & 1.05 & 0.08 & 2.00 & 1.00 & - & 2.81 & 0.81 & 0.51 & \\
\hline Balteem & 5.60 & 0.18 & 3.64 & 3.30 & - & 20.04 & 29.00 & 5.62 & \\
\hline
\end{tabular}

The abovementioned plastic tea cups were equally divided into six groups as every group contain 30 cups considered as a treatment (three replicate) and irrigated twice a weekly with suitable diluted seawater. The treatments were freshwater $(0 \%$ seawater) beside five diluted seawater percentages $(10,15,20,25$ and $50 \%$ seawater). Seawater was diluted with freshwater to the required levels $(0,10,15,20,25$ and $50 \%$ seawater) in a plastic tank. Some chemical properties of used seawater (collected from the sea in Balteem beach) and freshwater were shown in Table 2.

Table 2. Chemical analysis of seawater and tap water (Mean of both seasons)

\begin{tabular}{lllllllllll}
\hline Sample & $\mathrm{pH}$ & $\mathrm{EC}\left(\mathrm{dSm}^{-1}\right)$ & $\mathrm{Na}^{+}(\mathrm{ppm})$ & $\mathrm{Cl}^{-}$ & $\mathrm{CO}_{3}{ }^{2-}(\mathrm{Meq} / \mathrm{l})$ & $\mathrm{Ca}^{2+}$ & $\mathrm{Mg}^{2+}$ & $\mathrm{N}(\%)$ & $\mathrm{P}(\mathrm{ppm})$ & $\mathrm{K}(\mathrm{ppm})$ \\
\hline Seawater & 8.11 & 52.63 & 11523 & 589.4 & 1.6 & 28 & 182 & 1.5 & 115.62 & 253 \\
Freshwater & 7.38 & 3.5 & 325.9 & 1.3 & 0.8 & 16.4 & 7.7 & 0.4 & 0.3 & 5.1 \\
\hline
\end{tabular}

ii. Second trial: Four weeks after the second sowing date (March $15^{\text {th }}$ ), the uniform seedlings of each diluted seawater level were transplanted into pots (one plant $/ 30 \mathrm{~cm}$ diameter plastic pots filled with $8-10 \mathrm{~kg}$ of the same experimental area soil) and remained in open atmosphere. The experiment was conducted in February $15-$ October 15 of 2012 and 2013 seasons in completely randomized design according to Snedecor and Cochran (1980) with three replications as every replicate contains five pots. Each pot received $500 \mathrm{ml} /$ pot twice a weekly of the same abovementioned diluted seawater concentrations throughout the course of the study. All plants received the recommended constant stand dose of NPK at the ratio of 1:1:1 at the rate of $5 \mathrm{~g} /$ pot. The application started two months after seed sowing and repeated every month till the termination of the experiment. The 
fertilizers applied for research plots were ammonium sulphate " $20 \% \mathrm{~N}$ ", calcium super phosphate " $15.5 \% \mathrm{P}_{2} \mathrm{O}_{5}$ " and potassium sulphate " $48 \% \mathrm{~K}_{2} \mathrm{O}$ ".

\subsection{Measurements}

Before start of the experiment both seawater and soil samples were transferred to the center laboratory of Kafr Elsheikh University for analyzing chemical constituents, electrical conductivity (EC) and pH. Two weeks after each monthly seeds sowing date, number of germinated seeds counted every three days till germination stop (during the period of February 15 - October 15 of each season) according to the rules of the Association of Official Seed Analysts (AOSA 1990). Seed germination percentage was calculated using the following equation:

$$
G \%=\frac{\text { No.of } . \text { germimated } . \text { seeds }}{\text { Total.seed } \text {.number }} \times 100
$$

At the end of the experiment (last week of November of each season), the growth criteria were measured (plant height, stem diameter, aerial parts fresh and dry weights, compound leaves number and area/ plant (the fourth leaf from five plants tip of each replicate were taken to leaf area determination using LI-3100C Area Meter), leaves fresh and dry weights/plant, roots number, roots fresh and dry weights/plant). Chemical constituents of leaves were determined at the harvest time as leaf total green color was measured using a portable chlorophyll meter (Minolta SPAD-502, Japan), total soluble protein was measured according to Bradford (1976) and total carbohydrates was determined by the calometric method (AOAC, 1990). Minerals contents (N, P, K, Na, Ca, Mg) were determined in samples of leaves dry powder as described by Cottenie et al. (1982).

\subsection{Statistical Analysis}

The experiments were conducted twice and the obtained data were subjected to statistical analysis of variance (ANOVA). ANOVA were computed using MSTAT-C (MSTAT Development Team 1989) and the mean separations were carried out according to Duncan's multiple range tests (Duncan, 1955) and significance was determined at $\mathrm{p}<0.05$ using MSTAT-C software.

\section{Results and Discussion}

3.1 Effect of Soil Type, Sowing Date and Diluted Seawater Irrigation on Moringa oleifera, Lam., Seed Germination Percentage

Germination percentage was taken as the only indicator for the success in moringa seed germination at the selected areas. Silty clay soil (Balteem area) surpassed clay soil (Kafr El-Sheikh area) in germination percentage in most sowing dates. As for sowing date, it was noted from Figure 1 that, germination percentage was very weak in the first schedule of the experiment (February, March and April) and then started to rise gradually with reasonable rates beginning from may even reach the highest germination percentages during June, July and August months and then taken to decline gradually until reaching very low at the end of the experiment (November).

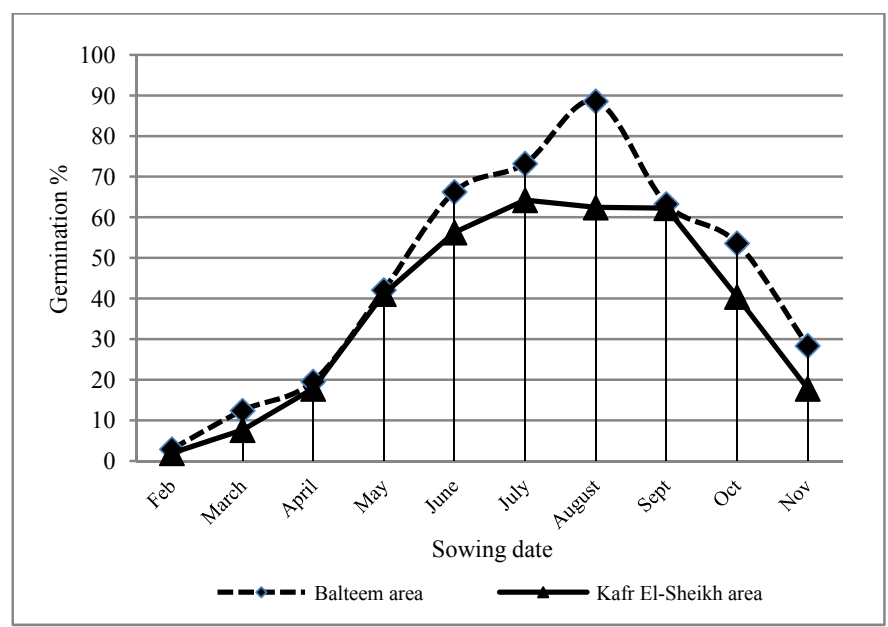

Figure 1. Effect of sowing date on Moringa oleifera, Lam., seed germination percentage

A low seawater ratios (10 and 15\%) gave germination percentage convergence with that obtained from 
freshwater in both studied areas (Figure 2). Germination percentage considerably decreased with the increase in seawater proportion (25\%) even almost nonexistent when the ratio became $50 \%$ seawater. Salinity stress may affects seed germination either through osmotic effects, by preventing or delaying germination (Welbaum et al., 1990), or through ion toxicity, which can render the seeds unviable (Huang \& Reddman, 1995). Mauromicale and Licandro (2002) found that salinity increase results in decrease in germinability and delayed rate of germination of globe artichoke. Higher germination percentage $(60 \%)$ of Halianthus annuus seeds was observed when sandy media was used. However, low germination percentage (40\%) was observed in the clay treatments (Ogboghodo \& Omonhinmin, 2003).

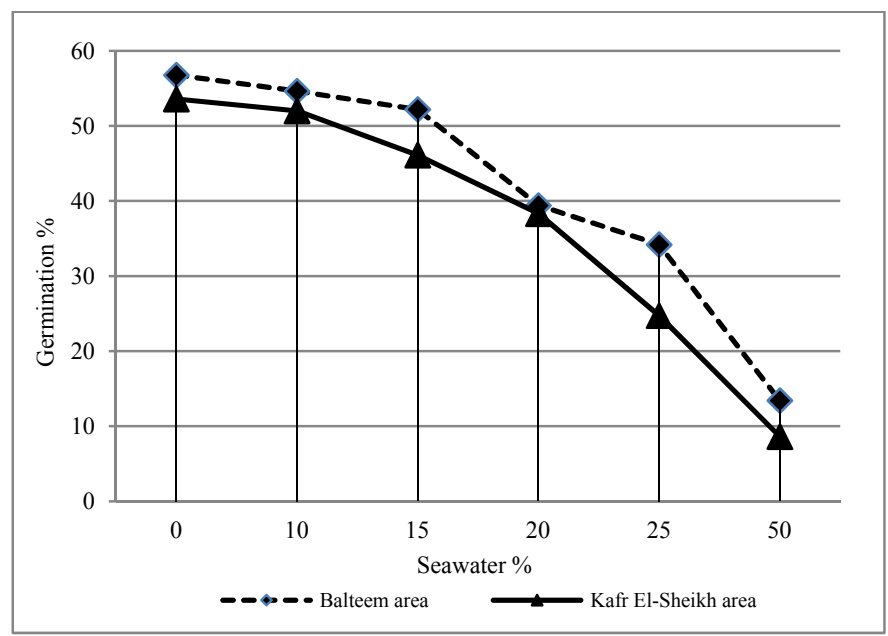

Figure 2. Effect of diluted seawater irrigation on Moringa oleifera, Lam., seed germination percentage

\subsection{Effect of Soil Type and Diluted Seawater Irrigation on Growth Characters and Some Chemical Constituents of Moringa oleifera, Lam.}

\subsubsection{Effect on Growth Characters}

i. Soil type: It was noticed that, Moringa oleifera, Lam., plants planted at Kafr El-Sheikh area were characterized with strong growth in general compared to that planted at Balteem area (Tables 3, 4 and 5). Kafr El-Sheikh area results were supreme for all growth characters except plant height, stem diameter and root fresh and dry weights. Superiority that appears in the results of Kafr El-Sheikh area plants is probably due to that, Kafr El-Shaikh area soil is clay whish features with not only high levels of both organic matter and mineral elements, but also, high capacity to retain water, compared to silty clay soil in Balteem area which is poor in many of these qualities. Gradually decrease in all studied growth characters may be due to that, highest percentage of seawater increased soil salinity which led to moringa plants deterioration. Soil salinity affects the plant growth by several physiological and biochemical means like ion toxicity, osmotic stress, nutritional imbalance and biochemical and negatively correlated with $\mathrm{Na}$ concentration. This nutritional imbalance resulted in the reduction of number of leaves and branches and stunted shoot growth in melon (Sivritepe et al., 2003). This is consistent with Innocent Pahla et al. (2013) who reported that, total plant dry matter increase as the clay content of the soil increased in the soil. They obtained 45 and $72.3 \mathrm{~g}$ of $M$. oleifera total dry matter when they used sandy and clay soil respectively. Soil texture is important factor where clays generally compromise the majority of cation exchange sites in soils. This is because clays by virtue of their small particle size have the most surface area and therefore the most exchange sites. Consequently, clay soils have the greatest risk for excess sodium binding and dispersion (Leal et al., 2009). 
Table 3. Effect of soil type and diluted seawater irrigation on plant height, stem diameter and aerial parts fresh weight of Moringa oleifera, Lam. (Mean of both seasons)

\begin{tabular}{|c|c|c|c|c|c|c|c|c|c|}
\hline \multirow{2}{*}{ Seawater $\%$} & \multicolumn{3}{|c|}{ Plant height $(\mathrm{cm})$} & \multicolumn{3}{|c|}{ Stem diameter $(\mathrm{cm})$} & \multicolumn{3}{|c|}{ Fresh aerial parts $(\mathrm{g})$} \\
\hline & Kafrelsheikh & Balteem & Mean & Kafrelsheikh & Balteem & Mean & Kafrelsheikh & Balteem & Mean \\
\hline 0 & $161.30 \mathrm{~d}$ & $175.0 \mathrm{~b}$ & $168.2 b$ & $1.94 \mathrm{~b}$ & $1.88 \mathrm{c}$ & $1.91 \mathrm{~b}$ & $170.50 \mathrm{~b}$ & $140.05 \mathrm{~g}$ & $155.31 \mathrm{~b}$ \\
\hline 10 & $168.43 \mathrm{c}$ & $177.15 \mathrm{a}$ & $172.80 \mathrm{a}$ & $2.05 \mathrm{a}$ & $1.80 \mathrm{~d}$ & $1.93 \mathrm{a}$ & $174.38 \mathrm{a}$ & $146.13 d$ & $160.32 \mathrm{a}$ \\
\hline 15 & $156.53 \mathrm{~g}$ & $160.88 \mathrm{e}$ & $158.70 \mathrm{c}$ & $1.80 \mathrm{~d}$ & $1.76 \mathrm{e}$ & $1.78 \mathrm{c}$ & $148.08 \mathrm{c}$ & $141.88 \mathrm{f}$ & $145.01 \mathrm{c}$ \\
\hline 20 & $156.07 \mathrm{~h}$ & $158.69 \mathrm{f}$ & $157.4 \mathrm{~d}$ & $1.74 \mathrm{f}$ & $1.66 \mathrm{~g}$ & $1.70 \mathrm{~d}$ & $145.67 \mathrm{e}$ & $127.68 \mathrm{i}$ & $136.70 \mathrm{~d}$ \\
\hline 25 & $137.44 \mathrm{i}$ & $131.77 \mathrm{j}$ & $134.6 \mathrm{e}$ & $1.46 \mathrm{i}$ & $1.54 \mathrm{~h}$ & $1.50 \mathrm{e}$ & $129.53 \mathrm{~h}$ & $93.56 \mathrm{j}$ & $111.50 \mathrm{e}$ \\
\hline 50 & 94.391 & $105.52 \mathrm{k}$ & $99.96 \mathrm{f}$ & $1.18 \mathrm{k}$ & $1.27 \mathrm{j}$ & $1.23 \mathrm{f}$ & $89.62 \mathrm{k}$ & 88.911 & $89.27 \mathrm{f}$ \\
\hline Mean & $145.7 \mathrm{~b}$ & $151.5 \mathrm{a}$ & & $1.70 \mathrm{a}$ & $1.70 \mathrm{a}$ & & $143.00 \mathrm{a}$ & $123.00 \mathrm{~b}$ & \\
\hline
\end{tabular}

$\overline{\text { Note. Means within a column having the same letters are not significantly different in Duncan's Multiple Range }}$ Test.

Table 4. Effect of soil type and diluted seawater irrigation on aerial parts dry weight, leaf number and leaf area of Moringa oleifera, Lam. (Mean of both seasons)

\begin{tabular}{|c|c|c|c|c|c|c|c|c|c|}
\hline \multirow{2}{*}{ Seawater \% } & \multicolumn{3}{|c|}{ Dry aerial parts $(\mathrm{g})$} & \multicolumn{3}{|c|}{ Leaf number } & \multicolumn{3}{|c|}{ Leaf area $\left(\mathrm{dm}^{2}\right)$} \\
\hline & Kafrelsheikh & Balteem & Mean & Kafrelsheikh & Balteem & Mean & Kafrelsheikh & Balteem & Mean \\
\hline 0 & $48.70 \mathrm{~b}$ & $42.32 \mathrm{e}$ & $45.50 \mathrm{~b}$ & $14.85 \mathrm{a}$ & $10.26 \mathrm{f}$ & $12.56 \mathrm{~b}$ & $19.93 b$ & $18.84 \mathrm{e}$ & $19.38 \mathrm{~b}$ \\
\hline 10 & $52.41 \mathrm{a}$ & $40.66 f$ & $46.39 \mathrm{a}$ & $14.51 \mathrm{~b}$ & $11.18 \mathrm{e}$ & $12.85 \mathrm{a}$ & $20.64 \mathrm{a}$ & $18.88 \mathrm{~d}$ & $19.76 \mathrm{a}$ \\
\hline 15 & $44.56 \mathrm{c}$ & $37.90 \mathrm{~h}$ & $41.20 \mathrm{c}$ & $12.72 \mathrm{c}$ & $9.80 \mathrm{~g}$ & $11.26 \mathrm{c}$ & $19.75 \mathrm{c}$ & $18.51 \mathrm{~g}$ & $19.13 \mathrm{c}$ \\
\hline 20 & $43.67 d$ & $34.77 \mathrm{i}$ & $39.22 \mathrm{~d}$ & $11.83 \mathrm{~d}$ & $9.67 \mathrm{~h}$ & $10.75 d$ & $18.81 \mathrm{f}$ & $17.57 \mathrm{~h}$ & $18.19 \mathrm{~d}$ \\
\hline 25 & $38.85 \mathrm{~g}$ & $26.85 j$ & $32.87 \mathrm{e}$ & $9.80 \mathrm{~g}$ & $7.48 \mathrm{j}$ & $8.64 \mathrm{e}$ & $15.66 \mathrm{i}$ & $10.87 \mathrm{j}$ & $13.27 \mathrm{e}$ \\
\hline 50 & $26.85 j$ & $25.71 \mathrm{k}$ & $26.30 \mathrm{f}$ & $7.74 \mathrm{i}$ & $7.05 \mathrm{k}$ & $7.40 \mathrm{f}$ & 8.80 & $9.68 \mathrm{k}$ & $9.24 \mathrm{f}$ \\
\hline Mean & $42.50 \mathrm{a}$ & $34.70 \mathrm{~b}$ & & $11.90 \mathrm{a}$ & $9.20 \mathrm{~b}$ & & $17.26 \mathrm{a}$ & $15.72 b$ & \\
\hline
\end{tabular}

Note. $\mathrm{dm}^{2}=\mathrm{cm}^{2} \times 0.01$; Means within a column having the same letters are not significantly different in Duncan's Multiple Range Test.

Table 5. Effect of soil type and diluted seawater irrigation on leaves and roots fresh and dry weights of Moringa oleifera, Lam. (Mean of both seasons)

\begin{tabular}{|c|c|c|c|c|c|c|c|c|c|c|c|c|}
\hline \multirow{2}{*}{ Seawater $\%$} & \multicolumn{3}{|c|}{ Leaf fresh weight (g) } & \multicolumn{3}{|c|}{ Leaf dry weight (g) } & \multicolumn{3}{|c|}{ Root fresh weight (g) } & \multicolumn{3}{|c|}{ Root dry weight (g) } \\
\hline & Kafrelsheikh & Balteem & Mean & Kafrelsheikh & Balteem & Mean & Kafrelsheikh & Balteem & Mean & Kafrelsheikh & Balteem & Mean \\
\hline 0 & $51.64 \mathrm{~b}$ & $46.29 \mathrm{f}$ & $48.97 \mathrm{~b}$ & $16.09 \mathrm{~d}$ & $14.76 \mathrm{~d}$ & $15.43 \mathrm{c}$ & $280.01 \mathrm{j}$ & $285.20 \mathrm{i}$ & $282.60 \mathrm{f}$ & $46.89 \mathrm{~h}$ & $55.82 \mathrm{f}$ & $51.35 \mathrm{~d}$ \\
\hline 10 & $54.61 \mathrm{a}$ & $47.94 \mathrm{e}$ & $51.28 \mathrm{a}$ & $18.13 \mathrm{a}$ & $15.18 \mathrm{e}$ & $16.66 \mathrm{a}$ & $274.93 \mathrm{k}$ & $298.44 \mathrm{~g}$ & $286.70 \mathrm{e}$ & $46.89 \mathrm{~h}$ & $55.82 \mathrm{f}$ & $51.35 \mathrm{~d}$ \\
\hline 15 & $50.70 \mathrm{c}$ & $38.60 \mathrm{~h}$ & $44.65 \mathrm{c}$ & $16.83 \mathrm{~b}$ & $14.60 \mathrm{~g}$ & $15.72 \mathrm{~b}$ & $297.66 \mathrm{~h}$ & $311.57 \mathrm{f}$ & $304.60 \mathrm{~d}$ & $47.64 \mathrm{~g}$ & $77.53 \mathrm{e}$ & $62.58 \mathrm{c}$ \\
\hline 20 & $48.33 \mathrm{~d}$ & $38.11 \mathrm{i}$ & $43.22 \mathrm{~d}$ & $16.23 \mathrm{c}$ & $14.02 \mathrm{i}$ & $15.13 \mathrm{~d}$ & $330.05 \mathrm{e}$ & $346.04 \mathrm{c}$ & $338.00 \mathrm{c}$ & $79.88 \mathrm{~d}$ & $85.03 \mathrm{~b}$ & $82.46 \mathrm{~b}$ \\
\hline 25 & $42.65 \mathrm{~g}$ & $37.08 \mathrm{j}$ & $39.86 \mathrm{e}$ & $14.22 \mathrm{~h}$ & $12.83 \mathrm{j}$ & $13.52 \mathrm{e}$ & $347.48 b$ & $364.71 \mathrm{a}$ & $356.10 \mathrm{a}$ & $82.90 \mathrm{c}$ & $85.57 \mathrm{a}$ & $84.24 \mathrm{a}$ \\
\hline 50 & $36.74 \mathrm{k}$ & 33.971 & $35.35 \mathrm{f}$ & $12.45 \mathrm{k}$ & 12.411 & $12.43 \mathrm{f}$ & $335.60 \mathrm{~d}$ & $364.71 \mathrm{a}$ & $350.20 \mathrm{~b}$ & $34.62 \mathrm{j}$ & $43.60 \mathrm{i}$ & $39.11 \mathrm{e}$ \\
\hline Mean & $47.40 \mathrm{a}$ & $40.30 \mathrm{~b}$ & & $15.70 \mathrm{a}$ & $14.00 \mathrm{~b}$ & & $311.00 \mathrm{~b}$ & $328.40 \mathrm{a}$ & & $56.50 \mathrm{~b}$ & $67.20 \mathrm{a}$ & \\
\hline
\end{tabular}

Note. Means within a column having the same letters are not significantly different in Duncan's Multiple Range Test.

ii. Diluted seawater: Data (Tables 3 and 5) revealed that lower percent (10 and 15\%) seawater in the irrigation gave equally good as freshwater in most studied growth characters for both areas. There was a negative relationship between seawater percent and most plant growth characters. Results were taken to gradually decline with the increase in the proportion of seawater until it reached a very low level unviable economically when the 
seawater percentage was $50 \%$ of the irrigation water. The ratio of $10 \%$ seawater at Kafr El-Sheikh area gave the tallest plants $(168.43 \mathrm{~cm})$, thickest stem $(2.05 \mathrm{~cm})$ and heaviest fresh and dry aerial parts while, fresh water only excelled in some growth characters as stem diameter $(1.88 \mathrm{~cm})$ and aerial parts dry weight $(42.32 \mathrm{~g})$ at Balteem area and leaves number (14.85) at Kafr El-Sheikh area. Negative relationship was shown between salt stress and plant growth characters i.e. plant height, green leaves area and dry weight of each root, stem, leaves and shoots which decreased as the salt concentration increased in the diluted seawater (Hussein et al., 2010; Hussein \& Abou-Baker, 2014). It was noticed from chemical analysis of seawater table that, seawater contain many fertilizer elements which may be encouraged plant growth. Fresh and dry weights of the tested plants increased with increasing concentration of seawater used for irrigation from $10 \%$ up to $15 \%$. But further increase in salinity level of the irrigation water tended to decrease the fresh and dry weights (Ashour et al., 1997 on the grass species). The decrease in photosynthesis under saline conditions is considered as one of the most important factor responsible for reduction of plant growth (Ball et al., 2004).

Also, leaf area and leaves fresh and dry weights take the same trend in the both areas as record 20,64 and 18,88 $\mathrm{dm}^{2}$ for leaf area, 54.61 and $47.94 \mathrm{~g}$ and 18.13 and $15.18 \mathrm{~g}$ for fresh and dry weights, respectively (Tables 4 and 5). This was followed by freshwater treatment in most cases which gave results equal or slightly less than $10 \%$ seawater treatment. The stimulatory effect of moderate salinity on the growth of some halophytic plants was also reported by O'Leary (1988), and may be attributed to improved shoot osmotic status as a result of increased ion uptake (Naidoo et al., 1995). Data show that, both root fresh and dry weights gradually increased with increasing seawater percentage till $25 \%$ seawater then, started to decrease at $50 \%$ seawater. This may be due to the increase in salinity stress with increasing seawater percentage in irrigation water. The increase in root fresh and dry weights at higher salinity suggests that, moringa roots have tendency to expansion and elongation under stresses conditions (Flowers \& Hajibagheri, 2001; Akhtar et al., 2003). Nouman et al. (2012) found that under saline environment, Moringa oleifera roots showed more ramification. Innocent Pahla et al. (2013) revealed different responses of $M$. oleifera in different soils. Root mass of 14 and $26.9 \mathrm{~g}$ were recorded in sandy and clay soils. They stated that, low yields in sandy soils compared to clay soils can be attributed to low soil nutrients.

\subsubsection{Effect on Leaves Chemical Constituents}

Total green color, total carbohydrates and mineral contents in moringa leaves were significantly affected with not only the increase in seawater percentage in the irrigation water but also the different experimental areas. Kafer El-Sheikh area recorded the best results for most studded chemical constituents. While the excellence fluctuations between each of the two seawater percentages of 0 and $10 \%$, as seawater $0 \%$ recorded the highest values for total green color and total carbohydrates contents whereas, seawater $10 \%$ excelled in total soluble protein content. The three the abovementioned contents were gradually decline with the increase in seawater percentage.

Moringa plants that were irrigated with low diluted seawater percentage (10\%) at Kafr El-Sheikh area gave the absolutely highest total green color, total soluble protein and total carbohydrates contents as recorded 37.48 SPAD, $3.76 \mathrm{mg} / 100$ g.d.w and 14.99 g/100 g.d.w, respectively (Table 6). Salinity caused reduction in chlorophyll content in combination with the reduced leaf area and growth (Shoresh et al., 2011). The photosynthesis is the most severely affected processes through salinity stress (Sudhir \& Merthy, 2004). Salt affects the photosynthesis apparatus but the researchers are still unclear about the factors, which are responsible for the inhibition of photosynthetic activity (Steduto et al., 2000). Also, Anwar et al. (2006) found no significant variation in the moringa protein contents from saline and non-saline areas. 
Table 6. Effect of soil type and diluted seawater irrigation on total green color, leaf protein and total carbohydrates of Moringa oleifera, Lam. (Mean of both seasons)

\begin{tabular}{|c|c|c|c|c|c|c|c|c|c|}
\hline \multirow{2}{*}{ Seawater \% } & \multicolumn{3}{|c|}{ Total green color (SPAD) } & \multicolumn{3}{|c|}{ Total soluble protein (mg/100 g.d.w.) } & \multicolumn{3}{|c|}{ Total carbohydrates (g/100 g.d.w.) } \\
\hline & Kafrelsheikh & Balteem & Mean & Kafrelsheikh & Balteem & Mean & Kafrelsheikh & Balteem & Mean \\
\hline 0 & $36.84 \mathrm{c}$ & $36.96 \mathrm{~b}$ & $36.90 \mathrm{a}$ & $3.70 \mathrm{~b}$ & $3.13 \mathrm{i}$ & $3.42 \mathrm{~b}$ & $14.91 b$ & $14.13 \mathrm{~d}$ & $14.52 \mathrm{a}$ \\
\hline 10 & $37.48 \mathrm{a}$ & $36.22 \mathrm{f}$ & $36,80 \mathrm{~b}$ & $3.76 \mathrm{a}$ & $3.21 \mathrm{~g}$ & $3.49 \mathrm{a}$ & $14.99 \mathrm{a}$ & $13.62 \mathrm{f}$ & $14.31 \mathrm{~b}$ \\
\hline 15 & $36.49 \mathrm{e}$ & $33.71 \mathrm{~g}$ & $35.10 \mathrm{~d}$ & $3.68 \mathrm{c}$ & $3.15 \mathrm{~h}$ & $3.42 b$ & $14.57 \mathrm{c}$ & $13.36 \mathrm{~g}$ & $13.97 \mathrm{c}$ \\
\hline 20 & $36.83 \mathrm{~d}$ & $33.50 \mathrm{i}$ & $35.17 \mathrm{c}$ & $3.49 \mathrm{e}$ & $3.08 \mathrm{j}$ & $3.29 \mathrm{c}$ & $14.05 \mathrm{e}$ & $12.50 \mathrm{i}$ & $13.27 \mathrm{~d}$ \\
\hline 25 & $33.17 \mathrm{j}$ & $33.68 \mathrm{~h}$ & $33.42 \mathrm{e}$ & $3.41 \mathrm{f}$ & $3.00 \mathrm{k}$ & $3.21 \mathrm{e}$ & $13.20 \mathrm{~h}$ & $12.33 \mathrm{j}$ & $12.76 \mathrm{e}$ \\
\hline 50 & 31.761 & $33.01 \mathrm{k}$ & $32.39 \mathrm{f}$ & $3.50 \mathrm{~d}$ & 2.961 & $3.23 \mathrm{~d}$ & $12.08 \mathrm{k}$ & 12.041 & $12.06 \mathrm{f}$ \\
\hline Mean & $35.40 \mathrm{a}$ & $34.50 \mathrm{~b}$ & & $3.60 \mathrm{a}$ & $3.10 \mathrm{~b}$ & & $14.00 \mathrm{a}$ & $13.00 \mathrm{~b}$ & \\
\hline
\end{tabular}

Note. Means within a column having the same letters are not significantly different in Duncan's Multiple Range Test.

It was noticed that, phosphorous, sodium and calcium contents gradually increased, while a significant depressions in $\mathrm{K}, \mathrm{Mg}$ and nitrogen content in both experimental areas with increasing seawater \% (Table 7). Kafer El-Sheikh area surpassed Balteem area in all cases. Seawater $10 \%$ was the best for $\mathrm{N} \%, \mathrm{~K} \%$ and $\mathrm{Mg}$ $\mathrm{mg} / 100 \mathrm{~g}$ whereas, seawater $50 \%$ gave the best results for both phosphorus and sodium contents. There were no significant differences among seawater at 10 or $20 \%$ for calcium contents. The highest phosphorous $(0.69$ pecent $)$ and sodium $(87.4 \mathrm{mg} / 100 \mathrm{~g})$ contents were recorded when $50 \%$ seawater used at Kafer El-Sheikh area. Calcium contents gave constant values at low seawater percentages (10-20\%) then begin to gradually decrease at both studied areas.

Table 7. Effect of soil type and diluted seawater irrigation on mineral constituents of Moringa oleifera, Lam. leaves (Mean of both seasons)

\begin{tabular}{|c|c|c|c|c|c|c|c|c|c|}
\hline \multirow{2}{*}{ Seawater \% } & \multicolumn{3}{|c|}{ N\% } & \multicolumn{3}{|c|}{$\mathrm{P} \%$} & \multicolumn{3}{|c|}{$\mathrm{K} \%$} \\
\hline & Kfs & Balt & Mean & Kfs & Balt & Mean & Kfs & Balt & Mean \\
\hline 0 & $3.08 \mathrm{c}$ & $2.36 \mathrm{~g}$ & $2.72 \mathrm{c}$ & $0.46 \mathrm{k}$ & 0.411 & $0.44 \mathrm{e}$ & $2.19 \mathrm{c}$ & $1.00 \mathrm{i}$ & $1.60 \mathrm{c}$ \\
\hline 10 & $3.36 \mathrm{a}$ & $2.99 \mathrm{~d}$ & $3.18 \mathrm{a}$ & $0.49 \mathrm{i}$ & $0.47 \mathrm{j}$ & $0.48 \mathrm{~d}$ & $2.31 \mathrm{a}$ & $1.12 \mathrm{~g}$ & $1.72 \mathrm{a}$ \\
\hline 15 & $3.11 \mathrm{~b}$ & $2.58 \mathrm{f}$ & $2.85 \mathrm{~b}$ & $0.53 \mathrm{~g}$ & $0.55 f$ & $0.54 \mathrm{c}$ & $2.23 b$ & $1.08 \mathrm{~h}$ & $1.66 \mathrm{~b}$ \\
\hline 20 & $2.66 \mathrm{e}$ & $2.14 \mathrm{~h}$ & $2.40 \mathrm{~d}$ & $0.57 \mathrm{~d}$ & $0.51 \mathrm{~h}$ & $0.54 \mathrm{c}$ & $2.03 \mathrm{~d}$ & $0.95 \mathrm{j}$ & $1.49 \mathrm{~d}$ \\
\hline 25 & $1.89 \mathrm{i}$ & $1.80 \mathrm{j}$ & $1.85 \mathrm{e}$ & $0.66 \mathrm{~b}$ & $0.56 \mathrm{e}$ & $0.61 \mathrm{~b}$ & $1.96 \mathrm{e}$ & $0.78 \mathrm{k}$ & $1.37 \mathrm{e}$ \\
\hline 50 & $1.63 \mathrm{k}$ & 1.311 & $1.47 \mathrm{f}$ & $0.69 \mathrm{a}$ & $0.62 \mathrm{c}$ & $0.66 \mathrm{a}$ & $1.27 \mathrm{f}$ & 0.751 & $1.01 \mathrm{f}$ \\
\hline Mean & $2.60 \mathrm{a}$ & $2.20 \mathrm{~b}$ & & $0.60 \mathrm{a}$ & $0.50 \mathrm{~b}$ & & $2.00 \mathrm{a}$ & $0.90 \mathrm{~b}$ & \\
\hline \multirow{2}{*}{ Seawater \% } & \multicolumn{3}{|c|}{$\mathrm{Na}(\mathrm{mg} / 100 \mathrm{~g})$} & \multicolumn{3}{|c|}{$\mathrm{Ca}(\mathrm{mg} / 100 \mathrm{~g})$} & \multicolumn{3}{|c|}{$\mathrm{Mg}(\mathrm{mg} / 100 \mathrm{~g})$} \\
\hline & Kfs & Balt & Mean & Kfs & Balt & Mean & Kfs & Balt & Mean \\
\hline 0 & $16.5 \mathrm{k}$ & 16.21 & $16.3 \mathrm{f}$ & $322 \mathrm{f}$ & $325 \mathrm{e}$ & $324 c$ & $851 \mathrm{e}$ & $735 \mathrm{k}$ & $793 e$ \\
\hline 10 & $24.9 \mathrm{i}$ & $19.4 \mathrm{j}$ & $22.2 \mathrm{e}$ & $328 \mathrm{~d}$ & $331 \mathrm{~b}$ & $330 \mathrm{ab}$ & $1102 \mathrm{a}$ & $955 \mathrm{~d}$ & $1029 \mathrm{a}$ \\
\hline 15 & $37.2 \mathrm{~g}$ & $28.7 \mathrm{~h}$ & $32.9 \mathrm{~d}$ & $330 \mathrm{c}$ & $328 d$ & $329 b$ & $1030 \mathrm{~b}$ & $788 \mathrm{~g}$ & $909 \mathrm{~b}$ \\
\hline 20 & $59.6 \mathrm{~d}$ & $41.0 \mathrm{f}$ & $50.3 \mathrm{c}$ & $333 a$ & $328 \mathrm{~d}$ & $331 \mathrm{a}$ & $958 \mathrm{c}$ & $743 j$ & $851 \mathrm{c}$ \\
\hline 25 & $75.5 b$ & $56.3 \mathrm{e}$ & $65.9 \mathrm{~b}$ & $284 \mathrm{~g}$ & $252 \mathrm{i}$ & $268 \mathrm{~d}$ & $833 \mathrm{f}$ & $757 \mathrm{i}$ & $795 \mathrm{~d}$ \\
\hline 50 & $87.4 \mathrm{a}$ & $68.9 \mathrm{c}$ & $78.1 \mathrm{a}$ & $260 \mathrm{~h}$ & $226 \mathrm{j}$ & $243 e$ & $759 \mathrm{~h}$ & 6901 & $724 f$ \\
\hline Mean & $50.2 \mathrm{a}$ & $38.4 \mathrm{~b}$ & & $310 \mathrm{a}$ & $298 \mathrm{~b}$ & & $922 a$ & $778 \mathrm{~b}$ & \\
\hline
\end{tabular}

Note. $\mathrm{Kfs}=$ Kafrelsheikh; Balt $=$ Balteem; Means within a column having the same letters are not significantly different in Duncan's Multiple Range Test.

The highest nitrogen, potassium and magnesium values were obtained when $10 \%$ seawater at Kafer El-Sheikh area was used. A positive correlation was found between both $\mathrm{Na}$ and $\mathrm{P}$ contents and seawater percentage, while $\mathrm{K}, \mathrm{Ca}$ and $\mathrm{Mg}$ were negatively correlated with seawater percentage. This may be due to that, at low percentages of seawater, plants could benefit of seawater minerals which considered as cheap fertilizer, which reflected as an 
improvement on plant growth. These results are in harmony with those obtained by Garg and Gupta (1996) as they reported that, salinity depressed $\mathrm{N}$ and $\mathrm{K}$ uptake while $\mathrm{Na}$ contents increased. The excessive Na inhibits the uptake of other essential minerals like K, Ca and Mg (Al-Karaki, 2000). The adverse effect of salinity on growth may be causes through three ways: reduced the available water in the root zone causing water deficit, phytotoxicity of ions such as $\mathrm{Na}^{+}$and $\mathrm{Cl}^{-}$and nutrient imbalance depressing uptake and transport of nutrients and $\mathrm{Na}^{+}$competes $\mathrm{K}^{+}$for binding sites essential for cellular function (Munns \& Tester, 2008). Accumulation of inorganic solutes, such as sodium and potassium can also play a role independently or in combination with other mechanisms in maintaining the osmotic imbalance caused by the salt stress and influence the osmotic potential adjustment of plant cells (Peng et al., 2004; El-Mahrouk et al., 2010) on buttonwood. Nitrogen content was significantly reduced by salt stress, especially in the leaves (Geissler et al., 2009).

\section{References}

Akhtar, S., Wahid, A., \& Rasul, E. (2003). Emergence, growth and nutrient composition of sugarcane sprouts under $\mathrm{NaCl}$ salinity. Biol. Plant, 46, 113-116. http://dx.doi.org/10.1023/A:1022326604192

Al-Karaki, G. N. (2000). Growth, water use efficiency and sodium and potassium acquisition by tomato cultivars grown under salt stress. J. Plant Nutr., 23, 1-8. http://dx.doi.org/10.1080/01904160009381992

Amaglo, N. K. (2007). Effects of spacing and harvest frequency on the growth and leave yield of moringa (Moringa oleifera, Lam.), a Leafy Vegetable Crop (Masters' thesis). KNUST, Ghana.

Anwar, F., Hussain, A. I., Ashraf, M., Jamail, A., \& Iqbal, S. (2006). Effect of salinity on yield and quality of Moringa oleifera seed oil. Grasas Y Aceites., 57(4), 394-401. http://dx.doi.org/10.3989/gya.2006.v57.i4.65

AOSA. (1990). Rules for testing seeds. J. Seed Technol., 12, 1-112.

Association of Official Analytical Chemist (AOAC). (1990). Protein (Crude) determination in Animal Feed: Copper Catalyst Kjeldahl Method. Official Methods of Analysis (15th ed., pp. 992-995). Washington DC.

Ashour, N. I., Serag, M. S., Abd El-Haleem, A. K., \& Mekki, B. B. (1997). Forage production from three grass species under saline irrigation in Egypt. J. Arid Environ., 37, 299-307. http://dx.doi.org/10.1006/jare.1997.0284

Ball, M. C., Shew, W. C., \& Anderson, J. (2004). Salinity induced potassium deficiency causes losses of photosystrm in leaves of the gray mangrove (Avicennia mariena) through depletion of atrazine binding polypeptide. Aust. J. of Plant Physiol., 14, 351-361. http://dx.doi.org/10.1071/PP9870351

Bradford, M. M. (1976). A rapid and sensitive method for the quantitation of microgram quantities of protein utilizing the principle of protein-dyebinding. Anal. Biochem., 72, 248-254. http://dx.doi.org/10.1016/0003-2697(76)90527-3

Cottenie, A., Verlo, M., Kiekeus, L., Velghe, G., \& Camerlynck, R. (1982). Chemical Analysis of plants and soils. Laboratory of Analytical and Agrochemistry State University, Ghent, Belgium.

Duncan, D. B. (1955). Multiple range and multiple F test. Biometrics., 11, 1-42. http://dx.doi.org/10.2307/3001478

El-Dabh, R. S., El-Khateeb, M. A., Mazher, A. A. M., \& Abd El-Badaie, A. A. (2011). Effect of salinity on growth and chemical constituents of Moringa oleifera, Lam. Bull. Fac. Agric., Cairo Univ., 62(3), 261-386.

El-Mahrouk, M. E., El-Nady, M. F., \& Hegazi, M. A. (2010). Effect of diluted seawater irrigation and exogenous proline treatments on growth, chemical composition and anatomical characteristics of (Conocarpus erectus L.). J. Agric. Res. Kafer El-Sheikh Univ., 36(4), 420-446.

Fang, S., \& Chen, X. L. (1997). Using shallow saline ground water for irrigation and regulating for soil salt-water regime. Irrig. Drain. Syst., 11, 1-14. http://dx.doi.org/10.1023/A:1005736708632

Flowers, T. J., \& Hajibagheri, M. A. (2001). Salinity tolerance in Hordeum vulgare: Ion concentration in root cells of cultivars differing in salt tolerance. Plant Soil, 231, 1-9. http://dx.doi.org/10.1023/A:1010372213938

Fuglie, L. J. (1999). The Miracle Tree: Moringa oleifera: Natural Nutrition for the Tropics (p. 68). Church World Service, Dakar. Revised in 2001 and published as The Miracle Tree: The Multiple Attributes of Moringa (p. 172).

Garg, B. K., \& Gupta, I. C. (1996). Physiology of salt tolerance of arid zone crops. I- Pearl millet. Current Agric., 20(1-2), 19-32. 
Geissler, N., Hussin, S., \& Koyro, H. W. (2009). Interactive effects of $\mathrm{NaCl}$ salinity and elevated atmospheric $\mathrm{Co}_{2}$ concentration on growth, photosynthesis, water relations and chemical composition of the potential cash crop halophyte Aster tripolium, L. Environ Exp Bot., 65, 220-231. $\mathrm{http}: / / \mathrm{dx}$.doi.org/10.1016/j.envexpbot.2008.11.001

Gleick, P. H. (1993). Water in Crisis: A Guide to the World's Fresh Water Resources. Oxford University Press, New York.

Huang, J., \& Reddman, R. E. (1995). Salt tolerance of Hordeum and Brassica species during germination and early seedling growth. Can. J. Plant. Sci., 75, 815-819. http://dx.doi.org/10.4141/cjps95-137

Hussein, M. M., \& Abou-Baker, N. H. (2014). Growth and mineral status of moringa plants as affected by silicate and salicylic acid under salt stress. IJPSS., 3(2), 163-177. http://dx.doi.org/10.9734/IJPSS/2014/6105

Hussein, M. M., Shaaban, S. M., \& El-Ashry, S. M. (2010). Influence of diluted Sea Water and Foliar Fertilizer on hydrophysical properties of a clayey soil in relation to growth, yield and mineral status of millet. $J$. of New York Sci., 3(7).

Innocent, P., Fanuel, T., Simbarashe, M., \& James, C. (2013). Effects of soil type and manure level on the establishment and growth of Moringa oleifera. Inter. J. Agric. and Forest., 3(6), 226-230.

Jin, M. G., Zhang, R. Q., Sun L. F., \& Gao, Y. F. (1999). Temporal and spatial soil water management: A case study in the Heilonggang region, PR China. Agr. Water Manage., 42, 173-187. http://dx.doi.org/10.1016/S0378-3774(99)00039-6

Jin, Z. M., Wang, C. H., Liu, Z. P., \& Gong, W. J. (2007). Physiological and ecological characters studies on Aloe vera under soil salinity and seawater irrigation. Process Biochem., 42, 710-714. http://dx.doi.org/10.1016/j.procbio.2006.11.002

Joly, A. B. (1979). Botânica - Introdução à taxonomia vegetal. Companhia Editora Nacional (5th ed., p. 777). São Paulo, Brasil.

Leal, R. M., Herpin, U. W. E., Da Fonseca, A. F., Firme, L. P., Montes, C. R., \& Melfi, A. J. (2009). Sodicity and salinity in a Brazilian Oxisol cultivated with sugarcane irrigated with wastewater. Agricultural Water Manage., 96(2), 307-316. http://dx.doi.org/10.1016/j.agwat.2008.08.009

Liu, Z. P., Liu, L., Chen, M. D., Deng, L. Q., Zhao, G. M., Tang, Q. Z., \& Xia, T. X. (2003). Study on the irrigation systems in agriculture by seawater. J. Nat. Resour., 18, 423-429.

MSTAT Development Team. (1989). Mstat User's Guide: A microcomputer program for the design management and analysis research experiments. Michigan State Univ. East Lansing, USA.

Munns, R., \& Tester, M. (2008). Mechanism of salinity tolerance. Ann. Rev. Plant Biol., 59, 651-81. http://dx.doi.org/10.1146/annurev.arplant.59.032607.092911

Mauromicale, G., \& Licandro, P. (2002). Salinity and Temperature effects on germination, emergence and seedling growth of globe artichoke. Agronomie., 22, 443-450. http://dx.doi.org/10.1051/agro:2002011

Naidoo, J., Jahnke, J., \& Willert, Von D. J. (1995). Gas exchange responses of the $\mathrm{C}_{4}$ grass Sporobolus virginicus (Poaceae) to salinity stress. In A. M. Khan \& I. A. Ungar (Eds.), Biology of Salt Tolerant Plants (pp. 121-130). Karachi: University of Karachi.

Nouman, W., Siddiqui, M. T., Basra, S. M. A., Khan, R. A. T., Gull, M. E. O., \& Munir, H. (2012). Response of Moringa oleifera to saline conditions. Int. J. Agric. Biol., 14, 757-762.

Ogboghodo, I. A., \& Omonhinmin, A. C. (2003). Effect of soil types on seed germination of Halianthus annuus, L. Agricultural Sci. Digest, 23(2), 101-103.

O'Leary, J. W. (1988). Saline environments and halophytic crops. In E. E. Whitehead, C. F. Hutchinson, B. N. Timmermam \& R. G. Varady (Eds.), Arid Lands: Today and tomorrow (pp. 773-790). Boulder, CO: Westview Press, London and Belhaven Press.

Peixoto, R. O. J., Silva, G. C., Costa, R. A., Joseíres, L. S. F., Vieira, G. H. F., Filho, A. A. F., \& Vieira, H. S. F. R. (2011). In vitro antibacterial effect of aqueous and ethanolic moringa leaf extracts. Asian Pacific J. Trop. Med., 4(3), 201-204. http://dx.doi.org/10.1016/S1995-7645(11)60069-2

Peng, Y. H., Zhu, Y. F., Mao, Y. Q., Wang, S. W., Su, W. A., \& Tang, Z. C. (2004). Alkali grass resists salt stress through high $\left[\mathrm{K}^{+}\right]$and an endodermis barrier to $\mathrm{Na}^{+}$. J. Exp. Bot., 55, 939-949. 
http://dx.doi.org/10.1093/jxb/erh071

Pontual, V. E., Belany, E. A. C., Bezerra, S. R., Coelho, C. B. B. L., Napoleão, H. T., \& Paiva, M. G. P. (2012). Caseinolytic and milk-clotting activities from Moringa oleifera flowers. Food Chem., 135(3,1), 1848-1854. http://dx.doi.org/10.1016/j.foodchem.2012.06.087

Ramachanran, C., Peter, K. V., \& Gopalakrishan, P. K. (1980). Drumstick (Moringa oleifera): A multipurpose tree Indian vegetable. Economic Botany., 34(3), 276-283. http://dx.doi.org/10.1007/BF02858648

Rashid, U., Anwar, F., Moser, B. R., \& Knothe, G. (2008). Moringa oleifera oil: A possible source of biodiesel. Bioresource Technology, 99, 8175-8179. http://dx.doi.org/10.1016/j.biortech.2008.03.066

Shoresh, M., Spivak, M., \& Bernstein, N. (2011). Involvement of calcium-mediated effects on ROS metabolism in the regulation of growth improvement under salinity. Free Radical Biology \& Medicine., 51, 1221-1234. http://dx.doi.org/10.1016/j.freeradbiomed.2011.03.036

Sivritepe, N., Sivritepe, H. O., \& Eris, A. (2003). The effects of $\mathrm{NaCl}$ priming on salt tolerance in melon seedlings grown under saline conditions. Sci. Hortic., $229-237$. http://dx.doi.org/10.1016/S0304-4238(02)00198-X

Snedecor, G. W., \& Cochran, W. G. (1980). Statistical Methods (7th ed.). Ames Iowa: The Iowa State University Press.

Steduto, P., Albrizio, R., Giorio, P., \& Sorrentino, G. (2000). Gas exchange response and stomatal and non-stomatal limitations to carbon assimilation of sunflower under salinity. Environ. Exp. Bot., 44, $243-255$. http://dx.doi.org/10.1016/S0098-8472(00)00071-X

Sudhir, P., \& Merthy, S. D. S. (2004). Effect of salt stress on basic process of photosynthesis. Phytosynthetica, 42 , 481-486. http://dx.doi.org/10.1007/S11099-005-0001-6

Welbaum, G. E., Shen, Z., Oluoch, M. O., \& Jett, L. W. (1998). The evolution and effects of priming vegetable seeds. Seed Technol., 20, 209-235.

\section{Copyrights}

Copyright for this article is retained by the author(s), with first publication rights granted to the journal.

This is an open-access article distributed under the terms and conditions of the Creative Commons Attribution license (http://creativecommons.org/licenses/by/3.0/). 